\title{
In Vivo Determination of Vitamin D Function Using Transgenic Mice Carrying a Human Osteocalcin Luciferase Reporter Gene
}

\author{
Tomoko Nakanishi, ${ }^{1,2}$ Rumiko Saito, ${ }^{1}$ Makoto Taniguchi, ${ }^{1}$ Haruka Oda, ${ }^{1}$ Atsumi Soma, \\ Mayu Yasunaga, ${ }^{1}$ Mariko Yamane, ${ }^{1}$ and Kenzo Sato ${ }^{1,2}$ \\ ${ }^{1}$ Division of Molecular Biology, School of Life Sciences, Faculty of Medicine, Tottori University, Yonago, Nishicho 86, \\ Tottori 683-8503, Japan \\ ${ }^{2}$ Chromosome Engineering Research Center, Tottori University, Yonago, Tottori 683-8503, Japan \\ Correspondence should be addressed to Tomoko Nakanishi; tomo@med.tottori-u.ac.jp
}

Received 5 July 2012; Revised 15 February 2013; Accepted 26 February 2013

Academic Editor: Elena Orlova

Copyright (C) 2013 Tomoko Nakanishi et al. This is an open access article distributed under the Creative Commons Attribution License, which permits unrestricted use, distribution, and reproduction in any medium, provided the original work is properly cited.

\begin{abstract}
Vitamin D is an essential factor for ossification, and its deficiency causes rickets. Osteocalcin, which is a noncollagenous protein found in bone matrix and involved in mineralization and calcium ion homeostasis, is one of the major bone morphogenetic markers and is used in the evaluation of osteoblast maturation and osteogenic activation. We established transgenic mouse line expressing luciferase under the control of a 10-kb osteocalcin enhancer/promoter sequence. Using these transgenic mice, we evaluated the active forms of vitamins D2 and D3 for their bone morphogenetic function by in vivo bioluminescence. As the result, strong activity for ossification was observed with $1 \alpha, 25$-hydroxyvitamin D3. Our mouse system can offer a feasible detection method for assessment of osteogenic activity in the development of functional foods and medicines by noninvasive screening.
\end{abstract}

\section{Introduction}

Vitamin $\mathrm{D}$ is an essential factor for ossification, including activation of calcium absorption in the intestine, inhibition of calcium release in the kidney, and promotion of osteogenesis in bone. Indeed, vitamin D deficiency is well known to induce bone-softening diseases, such as rickets in children and osteomalacia in adults $[1,2]$. Vitamin $D$ is generated as previtamin D from 7-dehydrocholesterol by ultraviolet light irradiation of the mammalian skin and absorbed from various foods [3]. Animal foods contain vitamin D3 (cholecalciferol), while vegetable foods are enriched in vitamin D2 (ergocalciferol). The active form of vitamin $\mathrm{D}, 1 \alpha, 25$-hydroxyvitamin $\mathrm{D}$ $\left[1 \alpha, 25(\mathrm{OH})_{2} \mathrm{D}\right]$, is converted from previtamin $\mathrm{D}$ in the liver followed by the kidney $[4,5]$.

Osteocalcin, which is a noncollagenous protein found in bone matrix and involved in mineralization and calcium ion homeostasis, is one of the major bone morphogenetic markers and is used in the evaluation of osteoblast maturation and osteogenic activation [6-8]. The osteocalcin gene is regulated by various growth factors, hormones, cytokines, and vitamins. Basic fibroblast growth factor [9], bone morphogenetic proteins 2 and $4[10,11]$, and parathyroid hormone [12] are the major positive regulatory factors for osteocalcin gene expression, as well as vitamin $\mathrm{D}$. The promoter region of the osteocalcin gene contains some transcriptional regulatory elements, such as the AP-1/VDRE (AV) element composed of a vitamin D-responsive element (VDRE), retinoic acidresponsive element (RE), and Jun-Fos-responsive AP-1 [13], as well as osteoblast-specific factor-binding elements (OSE1 and OSE2) [14]. The vitamin D receptor activated by association of vitamin $\mathrm{D}$ promotes transcription of the osteocalcin gene through interaction with a VDRE in the promoter of the gene [15].

Previously, we produced a transgenic mouse line expressing luciferase under the control of a 10-kb human osteocalcin enhancer/promoter sequence. This mouse line was backcrossed with a hairless mouse line to enable us to monitor 
bone formation during growth, fracture repair, and aging using in vivo imaging, without sacrificing the mice [16]. Using this system, we evaluated vitamin D function using osteocalcin gene expression as an indicator.

\section{Materials and Methods}

2.1. Ethics Statement. All of the animal experiments described were approved by the Institutional Animal Care and Use Committee of Tottori University (Permission nos. 18-2-42 and 09-Y-64). All the mice received humane care in compliance with Tottori University's guidelines for the care and use of laboratory animals in research.

2.2. Cell Culture and Reporter Assays. MG-63 human osteosarcoma cells and HeLa cells were cultured in Eagle's minimal essential medium and Dulbecco's modified Eagle's medium supplemented with $10 \%$ fetal bovine serum (Thermo Fisher Scientific Inc., Waltham, MA), $100 \mathrm{U} / \mathrm{mL}$ penicillin (Meiji Seika Pharma Co. Ltd., Tokyo, Japan), and $0.1 \mathrm{mg} / \mathrm{mL}$ streptomycin (Meiji Seika Pharma Co. Ltd.) at $37^{\circ} \mathrm{C}$ under 5\% $\mathrm{CO}_{2}$ in air. For luciferase reporter assays, $2 \mu \mathrm{g}$ of pOC-Luc (luciferase gene with the human osteocalcin enhancer/promoter) or $\mathrm{p} \Delta \mathrm{OC}$-Luc (luciferase gene without the osteocalcin enhancer/promoter) was cotransfected into MG-63 or HeLa cells $\left(1 \times 10^{5}\right)$ using TransIT-LT1 (Mirus Bio LLC, Madison, WI) with $0.1 \mu \mathrm{g}$ of pRL-TK (TOYO B-Net, Tokyo, Japan), a plasmid carrying the Renilla luciferase gene driven by the thymidine kinase minimal promoter as an internal control. Dimethylsulfoxide (DMSO) as the vehicle or $1 \mathrm{nM}$ of previtamin D2 (Sigma-Aldrich Co., St. Louis, MO, USA), previtamin D3 (Sigma-Aldrich), $1 \alpha, 25(\mathrm{OH})_{2} \mathrm{D} 2$ (Sigma-Aldrich), and $1 \mathrm{nM} 1 \alpha, 25(\mathrm{OH})_{2} \mathrm{D} 3$ (Merck KGaA, Darmstadt, Germany) in DMSO (0.01\% final DMSO concentration) were added at the same time as the transfection. At $24 \mathrm{~h}$ after the transfection, the cells were solubilized and the luciferase activities were measured using a Pikkagene Dual Luciferase Assay System (TOYO B-Net). The firefly luciferase activity was normalized by the Renilla luciferase activity in the same sample.

2.3. In Vivo Luminescence Imaging. Hairless human osteocalcin enhancer/promoter-luciferase transgenic mice (OCLuc Tg mice) [16] were anesthetized with isoflurane (DS Pharma Animal Health Co. Ltd., Osaka, Japan) at 811 months of age and then injected subcutaneously with luciferin (Promega, Madison, WI) at a dose of $160 \mathrm{mg} / \mathrm{kg}$ body weight $(40 \mathrm{mg} / \mathrm{mL}$ luciferin). After $8 \mathrm{~min}$, the mice were placed on their ventral surface, and images of the luciferase activity were continuously acquired every $3 \mathrm{~min}$ until the maximal activity was detected using an IVIS Lumina Imaging System (Xenogen Corp., Alameda, CA). The luciferase activity tended to reach its peak at around $15 \mathrm{~min}$. To analyze the responsiveness to previtamin D3 (Sigma-Aldrich Co.), previtamin D2 (Sigma-Aldrich Co.), $1 \alpha, 25(\mathrm{OH})_{2} \mathrm{D} 3(\mathrm{Merck} \mathrm{KGaA})$, and $1 \alpha, 25(\mathrm{OH})_{2} \mathrm{D} 2$ (SigmaAldrich Co.), the luciferase activity was measured at 0, 6, 9, and $24 \mathrm{~h}$ after oral administration of each agent at a dose of $2 \mathrm{ng} / \mathrm{g}$ body weight. The acquired images were analyzed using Live Image 2.6 software (Xenogen Corp.) to quantify the luciferase activity.

2.4. Statistical Analysis. Statistical analysis was performed using StatView (SAS Institute Inc., Cary, NC). The Student's $t$-test was used to analyze the difference between the study and control groups.

\section{Results and Discussion}

3.1. Response of the Human Osteocalcin Enhancer/PromoterLuciferase Construct to $1 \alpha, 25(\mathrm{OH})_{2} \mathrm{D} 3$ In Vitro. We previously constructed a plasmid expressing luciferase under the control of a $10-\mathrm{kb}$ human osteocalcin enhancer/promoter sequence (pOC-Luc) (Figure 1(a)) [16]. Osteocalcin is a gene that is predominantly expressed in bone-associated tissues. The fragment contains a VDRE, a GAGA DNA motif, which is suggested to control the $1 \alpha, 25(\mathrm{OH})_{2} \mathrm{D} 3$ responsiveness of the rat osteocalcin gene $[17,18]$, as well as a TATA box. The osteocalcin translation start codon, ATG, was fused to the ATG of the luciferase gene. To insulate the transgenes from chromosomal position effects in the transgenic mice, two copies of the 1.2 -kb chicken $\beta$-globin $5^{\prime}$-HS4 element were inserted at both ends.

The regulation of pOC-Luc was monitored by its luciferase activity following transfection into MG-63 cells. The MG-63 cell line is a well-characterized human osteoblastlike cell line that shows $1 \alpha, 25(\mathrm{OH})_{2} \mathrm{D} 3$-dependent stimulation of osteocalcin production $[16,19]$. The luciferase activity of pOC-Luc was high compared with that of pOCALuc, containing approximately $60 \mathrm{bp}$ of the $5^{\prime}$-untranslated sequence. When the transfected cells were treated with $1 \alpha, 25(\mathrm{OH})_{2} \mathrm{D} 3$ and $1 \alpha, 25(\mathrm{OH})_{2} \mathrm{D} 2$, the luciferase activity of pOC-Luc was stimulated by approximately 10- and 2fold, respectively (Figure 1(b)). On the other hand, there was no stimulation by previtamin D3 and D2 treatment. In HeLa cells, the pOC-Luc activity and the induction by $1 \alpha, 25(\mathrm{OH})_{2} \mathrm{D} 3$ and $1 \alpha, 25(\mathrm{OH})_{2} \mathrm{D} 2$ was less compared to MG-63 cells (Figure 1(b)). These findings suggest that pOCLuc would be a useful tool for measuring bone-specific $1 \alpha, 25(\mathrm{OH})_{2} \mathrm{D} 3$ induction of the human osteocalcin gene.

\subsection{Effects of Oral Administration of Vitamins D3 and D2} on Osteocalcin Gene Expression in OC-Luc Tg Mice. We previously established a transgenic mouse line, OC-Luc Tg, harboring the human osteocalcin enhancer/promoterluciferase gene derived from pOC-Luc [16]. When the OCLuc Tg mouse line was backcrossed to a hairless mouse line, bioluminescence was observed along the bones after luciferin administration by in vivo imaging [16]. Consistent with the response of MG-63 cells to $1 \alpha, 25(\mathrm{OH})_{2} \mathrm{D} 3$, the bioluminescence of the whole body of OC-Luc Tg mice after intraperitoneal injection of $1 \alpha, 25(\mathrm{OH})_{2} \mathrm{D} 3$ was more than twice that measured in mice treated with vehicle [16].

To compare the effects of $1 \alpha, 25(\mathrm{OH})_{2} \mathrm{D} 3$, previtamin D3, $1 \alpha, 25(\mathrm{OH})_{2} \mathrm{D} 2$, and previtamin $\mathrm{D} 2$ on the bone formation activity, we aimed to measure the alterations in human osteocalcin expression after oral administration of these 

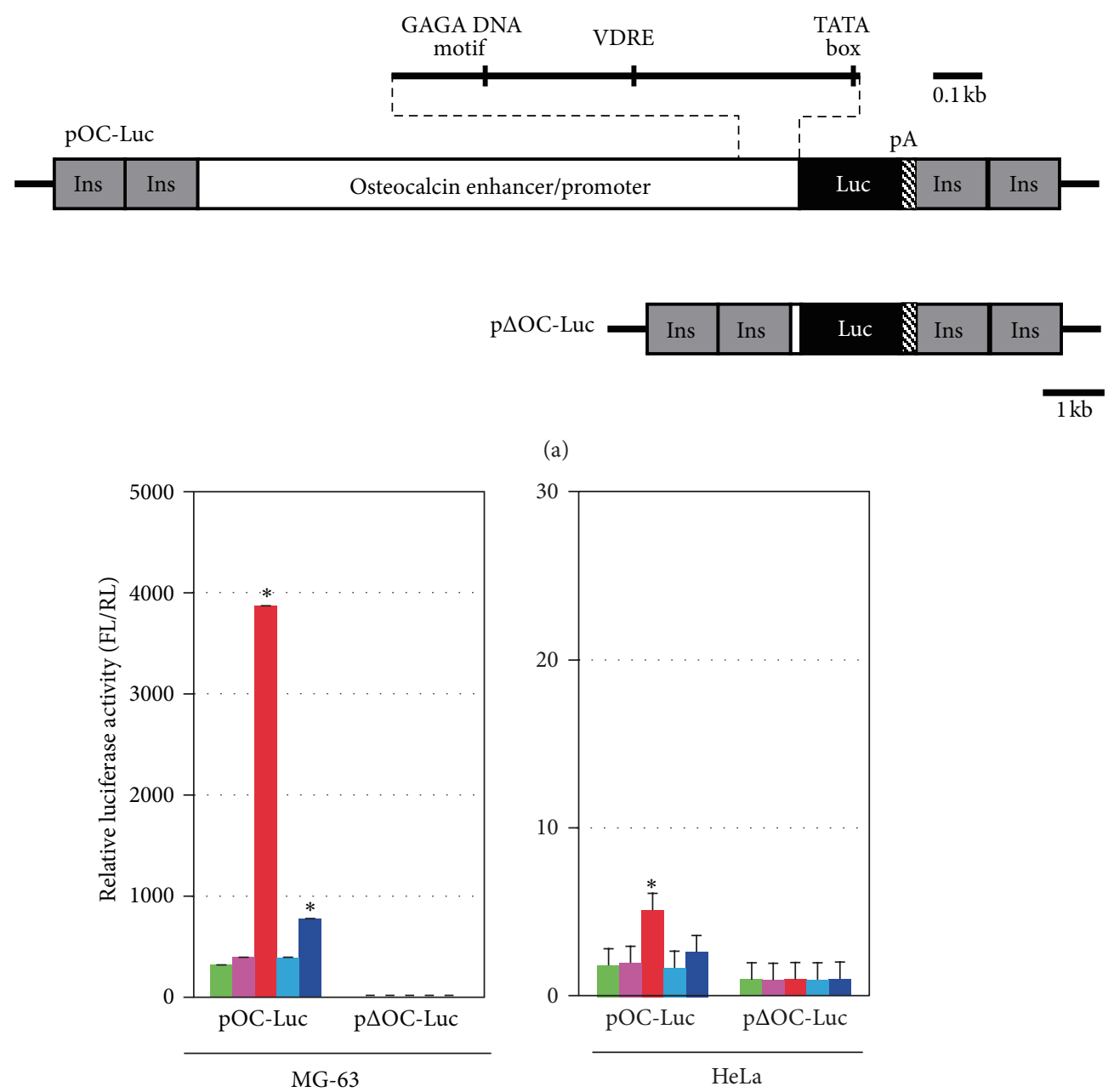

(a)

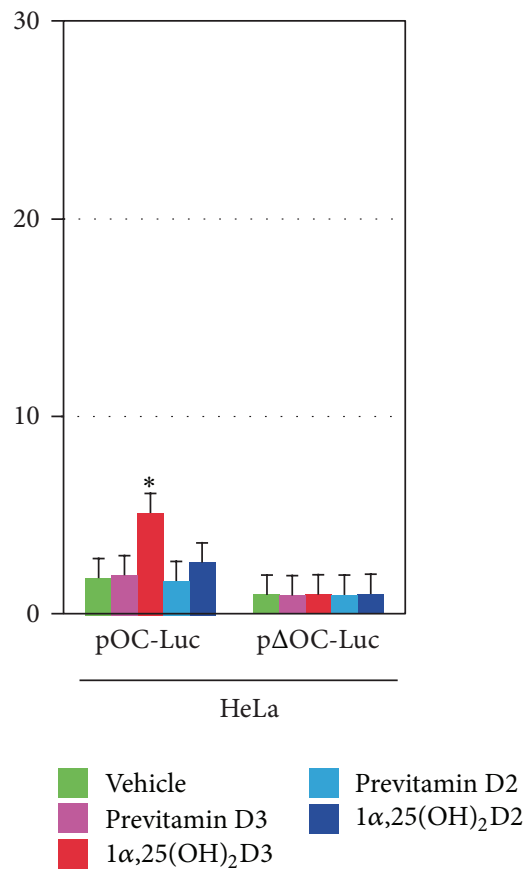

(b)

FIGURE 1: Constructs for the generation of the transgenic mice. (a) Schematic map of the transgenes used in the study. pOC-Luc is composed of a 10-kb human osteocalcin enhancer/promoter sequence, with $60 \mathrm{bp}$ of the $5^{\prime}$-untranslated sequence (white box), a luciferase gene (black box), an SV40 late polyadenylation signal (striped box), and an insulator sequence (gray box). (b) Enhanced expression of pOCLuc by $1 \alpha, 25(\mathrm{OH})_{2} \mathrm{D} 3$ treatment. MG-63 and HeLa cells transfected with pOC-Luc or $\mathrm{p} \Delta \mathrm{OC}$-Luc were incubated with $1 \mathrm{nM}$ previtamin D3, $1 \alpha, 25(\mathrm{OH})_{2} \mathrm{D} 3$, previtamin $\mathrm{D} 2,1 \alpha, 25(\mathrm{OH})_{2} \mathrm{D} 2$, or vehicle, and then subjected to luciferase reporter assays. The $y$-axis shows the relative luciferase activity, representing the firefly luciferase (FL) activity from the reporter plasmid normalized by the Renilla luciferase (RL) activity from the control vector. Statistical analysis was performed by Student's $t$-test; ${ }^{*} P<0.005$ relative to vehicle.

agents to OC-Luc Tg mice. The bioluminescence of the whole body of OC-Luc Tg mice at $6 \mathrm{~h}$ after oral administration of $1 \alpha, 25(\mathrm{OH})_{2} \mathrm{D} 3$ was more than twice those measured in mice treated with previtamin D3 or vehicle (Figure 2(a)). When the bioluminescence was measured at $6 \mathrm{~h}$ after oral administration of $1 \alpha, 25(\mathrm{OH})_{2} \mathrm{D} 2$, weak induction was observed, similar to the case for mice treated with previtamin D2 or vehicle (Figure 2(a)). As shown in Figure 2(b), the increase in bioluminescence induced by $1 \alpha, 25(\mathrm{OH})_{2} \mathrm{D} 3$ reached its maximum level at 6-9 $\mathrm{h}$ after oral administration and returned to the control levels by $24 \mathrm{~h}$, as previously reported [16, 20], whereas weak induction was observed within $24 \mathrm{~h}$ after $1 \alpha, 25(\mathrm{OH})_{2} \mathrm{D} 2$ administration. These findings indicate that only $1 \alpha, 25(\mathrm{OH})_{2} \mathrm{D} 3$ is effective for increasing the bone formation activity after a single oral administration to OCLuc Tg mice, compared with $1 \alpha, 25(\mathrm{OH})_{2} \mathrm{D} 2$, previtamin D3, and previtamin D2.

The bone-mobilizing activity of $1 \alpha, 25(\mathrm{OH})_{2} \mathrm{D} 2$ was reported to be lower than expected from its vitamin $\mathrm{D}$ receptor (VDR) affinity, which is only 3 times less than that 

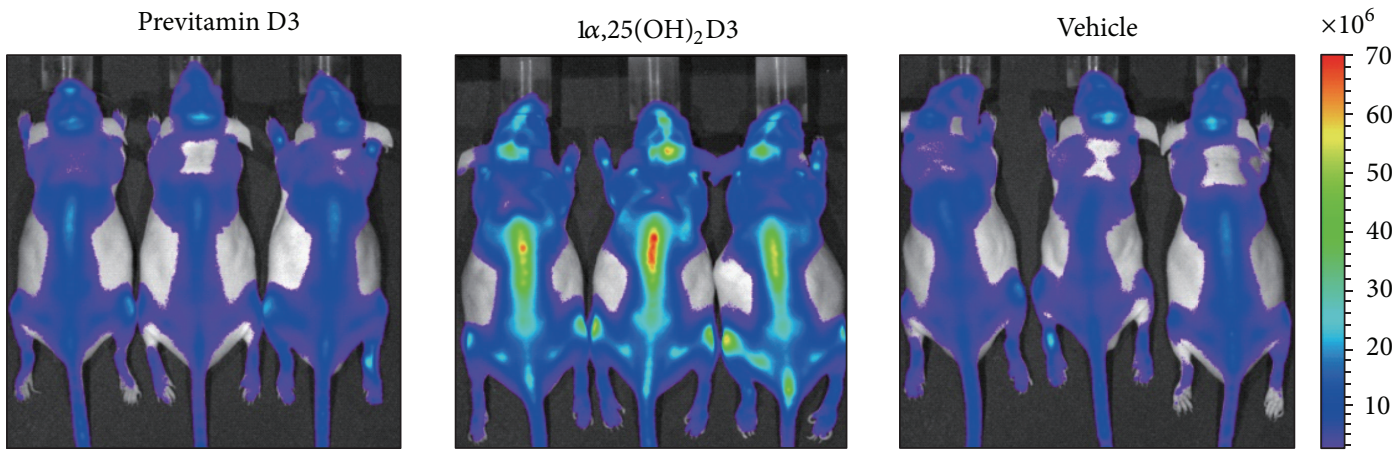

(a)
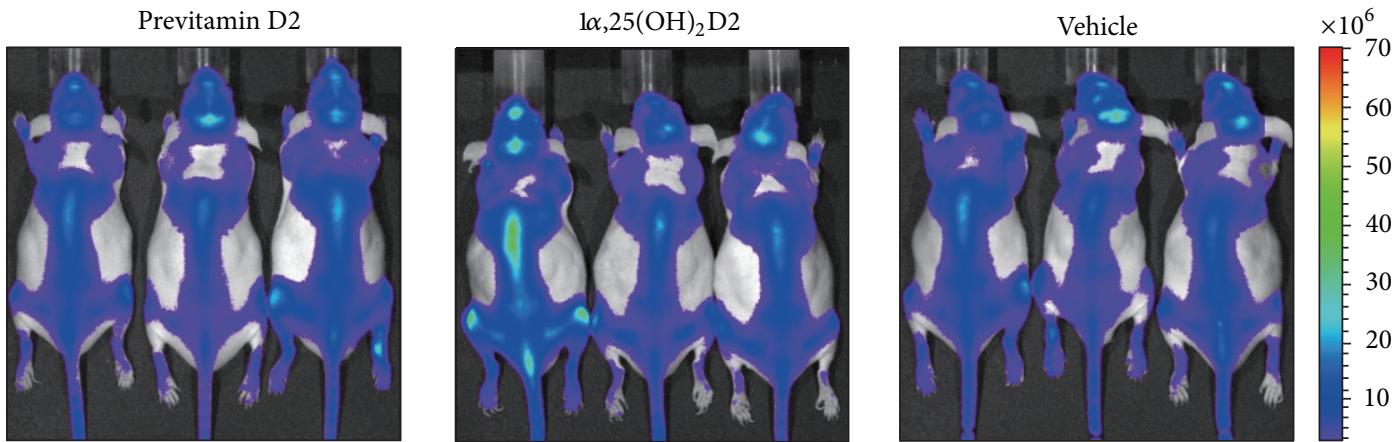

(b)

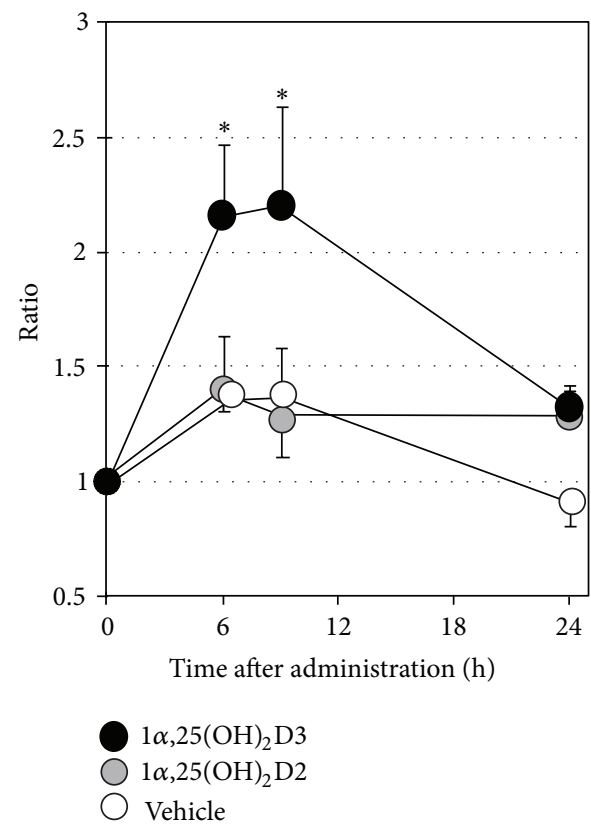

(c)

FIGURE 2: Regulation of the human osteocalcin enhancer/promoter by vitamins D3 and D2 in vivo. (a) Enhanced expression of the OC-Luc transgene by $1 \alpha, 25(\mathrm{OH})_{2} \mathrm{D} 3$ treatment. OC-Luc Tg mice were given a single oral administration of previtamin $\mathrm{D} 3,1 \alpha, 25(\mathrm{OH})_{2} \mathrm{D} 3$, or vehicle. In vivo bioluminescence imaging was performed at $6 \mathrm{~h}$ after the administration. (b) Response of the OC-Luc transgene to $1 \alpha, 25(\mathrm{OH})_{2} \mathrm{D} 2$ treatment. OC-Luc Tg mice were given a single oral administration of previtamin $\mathrm{D} 2,1 \alpha, 25(\mathrm{OH})_{2} \mathrm{D} 2$, or vehicle. In vivo bioluminescence imaging was performed at $6 \mathrm{~h}$ after the administration. (c) Time course of the induction of the OC-Luc transgene by vitamin D treatment. OC-Luc Tg mice were given a single oral administration of $1 \alpha, 25(\mathrm{OH})_{2} \mathrm{D} 3$ (filled circles), $1 \alpha, 25(\mathrm{OH})_{2} \mathrm{D} 2$ (shaded circles), or vehicle (open circles). The bioluminescence was analyzed at $0,6,9$, and $24 \mathrm{~h}$ after the administration using Living Image software and represented as the ratio of total flux (photons/second) compared to $0 \mathrm{~h}$. The data shown are means \pm SE $(n=3)$. Statistical analysis was performed by Student's $t$-test; ${ }^{*} P<0.05$ relative to vehicle. 
of $1 \alpha, 25(\mathrm{OH})_{2} \mathrm{D} 3$ [21]. Differential metabolism is a potential mechanism for the analog selectivity. Therefore, it is possible that $1 \alpha, 25(\mathrm{OH})_{2} \mathrm{D} 2$ may be catabolized more rapidly in bone. Another possible explanation for the difference in action between $1 \alpha, 25(\mathrm{OH})_{2} \mathrm{D} 3$ and $1 \alpha, 25(\mathrm{OH})_{2} \mathrm{D} 2$ is that $1 \alpha, 25(\mathrm{OH})_{2} \mathrm{D} 2$ does not mimic $1 \alpha, 25(\mathrm{OH})_{2} \mathrm{D} 3$ in upregulating the VDR. In addition, there is a lack of clarity in the literature as to whether there is a definitive difference between the effects of vitamins D2 and D3 on raising the serum 25hydroxyvitamin D levels in humans [22]. The precise processes that increase the bone formation activity through vitamins D3 and D2 currently remain unclear. It may be important to evaluate the differences between vitamins D3 and D2 utilizing an indicator related to a specific biological process.

\section{Conclusion}

In the transgenic mice harboring human osteocalcin enhancer/promoter luciferase reporter gene, strong osteogenic activity was observed by $1 \alpha, 25(\mathrm{OH})_{2} \mathrm{D} 3$ administration, compared with $1 \alpha, 25(\mathrm{OH})_{2} \mathrm{D} 2$, as well as previtamins D2 and D3. Our mouse system would offer a feasible detection method for assessing osteogenic activity in the development of functional foods and medicines by noninvasive screening.

\section{Acknowledgments}

The authors wish to thank Dr. Naohiro Hori and their laboratory members for technical assistance and valuable discussions. This study was supported in part by a City Area Program (basic stage), a Regional Innovation Cluster Program from the Ministry of Education, Culture, Sports, Science and Technology of Japan (MEXT).

\section{References}

[1] M. F. Holick, "Vitamin D deficiency," The New England Journal of Medicine, vol. 357, no. 3, pp. 266-281, 2007.

[2] D. D. Bikle, "Vitamin D and bone," Current Osteoporosis Reports, vol. 10, no. 2, pp. 151-159, 2012.

[3] M. F. Holick, J. A. MacLaughlin, and M. B. Clark, "Photosynthesis of previtamin D3 in human skin and the physiologic consequences," Science, vol. 210, no. 4466, pp. 203-205, 1980.

[4] M. F. Holick, "Resurrection of vitamin D deficiency and rickets," Journal of Clinical Investigation, vol. 116, no. 8, pp. 2062-2072, 2006.

[5] M. F. Holick and M. Garabedian, "Vitamin D: photobiology, metabolism, mechanism of action, and clinical applications," in Primer on the Metabolic Bone Diseases and Disorders of Mineral Metabolism, M. J. Favus, Ed., pp. 129-137, American Society for Bone and Mineral Research, Washington, DC, USA, 6th edition, 2006.

[6] R. M. Locklin, R. O. C. Oreffo, and J. T. Triffitt, "Modulation of osteogenic differentiation in human skeletal cells in vitro by 5-azacytidine," Cell Biology International, vol. 22, no. 3, pp. 207$215,1998$.

[7] J. Lemonnier, C. Ghayor, J. Guicheux, and J. Caverzasio, "Protein kinase $\mathrm{C}$-independent activation of protein kinase $\mathrm{D}$ is involved in BMP-2-induced activation of stress mitogenactivated protein kinases JNK and p38 and osteoblastic cell differentiation," Journal of Biological Chemistry, vol. 279, no. 1, pp. 259-264, 2004.

[8] S. L. Ferrari, L. Ahn-Luong, P. Garnero, S. E. Humphries, and S. L. Greenspan, "Two promoter polymorphisms regulating interleukin- 6 gene expression are associated with circulating levels of C-reactive protein and markers of bone resorption in postmenopausal women," Journal of Clinical Endocrinology and Metabolism, vol. 88, no. 1, pp. 255-259, 2003.

[9] M. Bodo, C. Lilli, C. Bellucci et al., "Basic fibroblast growth factor autocrine loop controls human osteosarcoma phenotyping and differentiation," Molecular Medicine, vol. 8, no. 7, pp. 393404, 2002.

[10] A. Yamaguchi, T. Ishizuya, N. Kintou et al., "Effects of BMP2, BMP-4, and BMP- 6 on osteoblastic differentiation of bone marrow-derived stromal cell lines, ST2 and MC3T3-G2/PA6," Biochemical and Biophysical Research Communications, vol. 220, no. 2, pp. 366-371, 1996.

[11] A. Yamaguchi, T. Komori, and T. Suda, "Regulation of osteoblast differentiation mediated by bone morphogenetic proteins, hedgehogs, and Cbfal," Endocrine Reviews, vol. 21, no. 4, pp. 393-411, 2000.

[12] X. P. Yu and S. Chandrasekhar, "Parathyroid hormone (PTH 1-34) regulation of rat osteocalcin gene transcription," Endocrinology, vol. 138, no. 8, pp. 3085-3092, 1997.

[13] R. Schüle, K. Umesono, D. J. Mangelsdorf, J. Bolado, J. W. Pike, and R. M. Evans, "Jun-Fos and receptors for vitamins A and $\mathrm{D}$ recognize a common response element in the human osteocalcin gene," Cell, vol. 61, no. 3, pp. 497-504, 1990.

[14] F. Yeung, W. K. Law, C. H. Yeh et al., "Regulation of human osteocalcin promoter in hormone-independent human prostate cancer cells," Journal of Biological Chemistry, vol. 277, no. 4, pp. 2468-2476, 2002.

[15] K. Ozono, J. Liao, S. A. Kerner, R. A. Scott, and J. W. Pike, “The vitamin D-responsive element in the human osteocalcin gene. Association with a nuclear proto-oncogene enhancer," Journal of Biological Chemistry, vol. 265, no. 35, pp. 21881-21888, 1990.

[16] T. Nakanishi, K. Kokubun, H. Oda et al., "Bioluminescence imaging of bone formation using hairless osteocalcin-luciferase transgenic mice," Bone, vol. 51, no. 3, pp. 369-375, 2012.

[17] N. A. Morrison, J. Shine, J. C. Fragonas, V. Verkest, M. L. McMenemy, and J. A. Eisman, "1,25-Dihydroxyvitamin Dresponsive element and glucocorticoid repression in the osteocalcin gene," Science, vol. 246, no. 4934, pp. 1158-1161, 1989.

[18] K. Yoon, S. J. C. Rutledge, R. F. Buenaga, and G. A. Rodan, "Characterization of the rat osteocalcin gene: stimulation of promoter activity by 1,25-dihydroxyvitamin $\mathrm{D}_{3}$," Biochemistry, vol. 27, no. 23, pp. 8521-8526, 1988.

[19] L. F. Bonewald, M. B. Kester, Z. Schwartz et al., "Effects of combining transforming growth factor $\beta$ and 1,25- dihydroxyvitamin $\mathrm{D}_{3}$ on differentiation of a human osteosarcoma (MG63)," Journal of Biological Chemistry, vol. 267, no. 13, pp. 89438949, 1992.

[20] N. A. Sims, C. P. White, K. L. Sunn et al., "Human and murine osteocalcin gene expression: conserved tissue restricted expression and divergent responses to 1,25- dihydroxyvitamin $\mathrm{D}_{3}$ in vivo," Molecular Endocrinology, vol. 11, no. 11, pp. 16951708, 1997.

[21] J. L. Finch, A. J. Brown, and E. Slatopolsky, "Differential effects of 1,25-dihydroxy-vitamin D3 and 19-nor-1,25- dihydroxyvitamin D2 on calcium and phosphorus resorption in bone," 
Journal of the American Society of Nephrology, vol. 10, no. 5, pp. 980-985, 1999.

[22] L. Tripkovic, H. Lambert, K. Hart et al., "Comparison of vitamin D2 and vitamin D3 supplementation in raising serum 25-hydroxyvitamin D status: a systematic review and metaanalysis," American Journal of Clinical Nutrition, vol. 95, no. 6, pp. 1357-1364, 2012. 


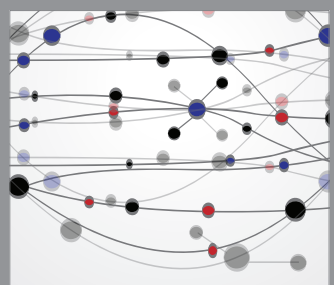

The Scientific World Journal
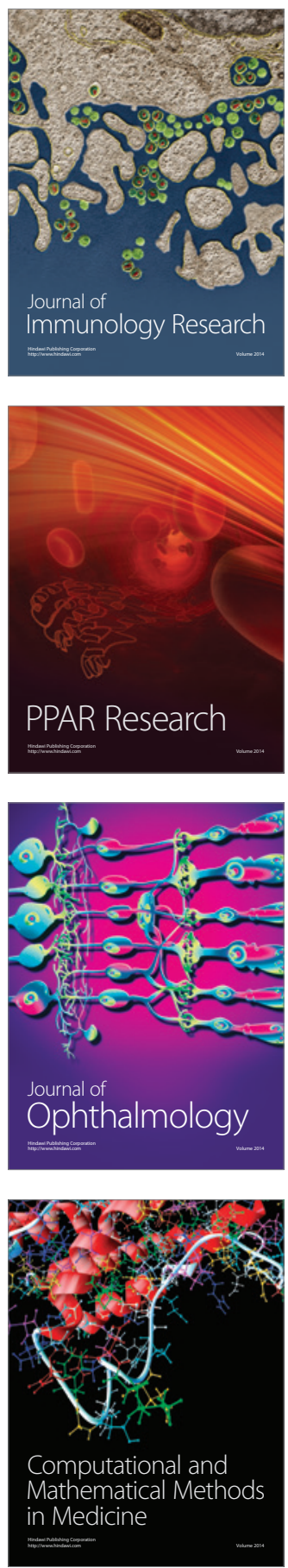

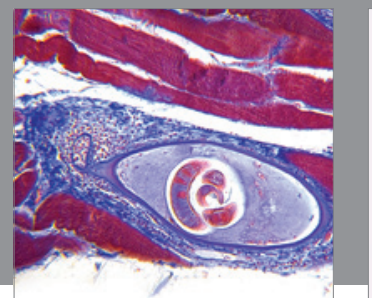

Gastroenterology

Research and Practice
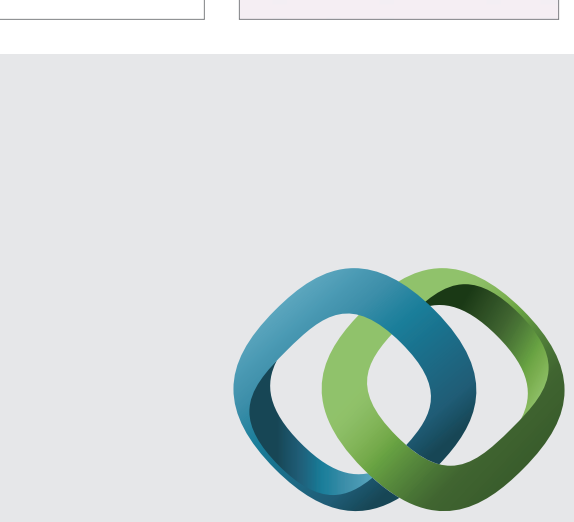

\section{Hindawi}

Submit your manuscripts at

http://www.hindawi.com
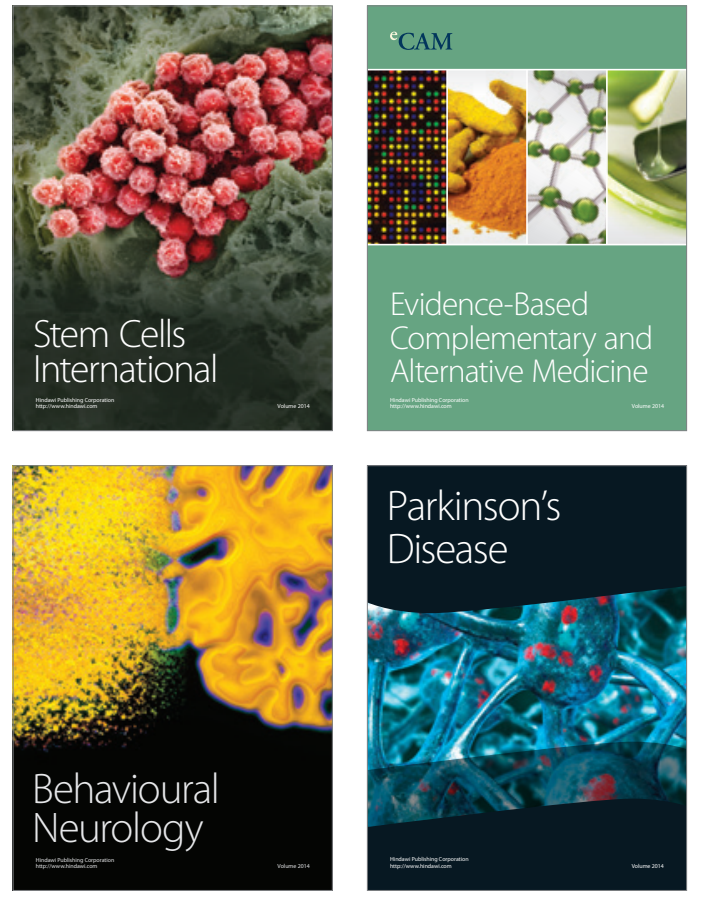
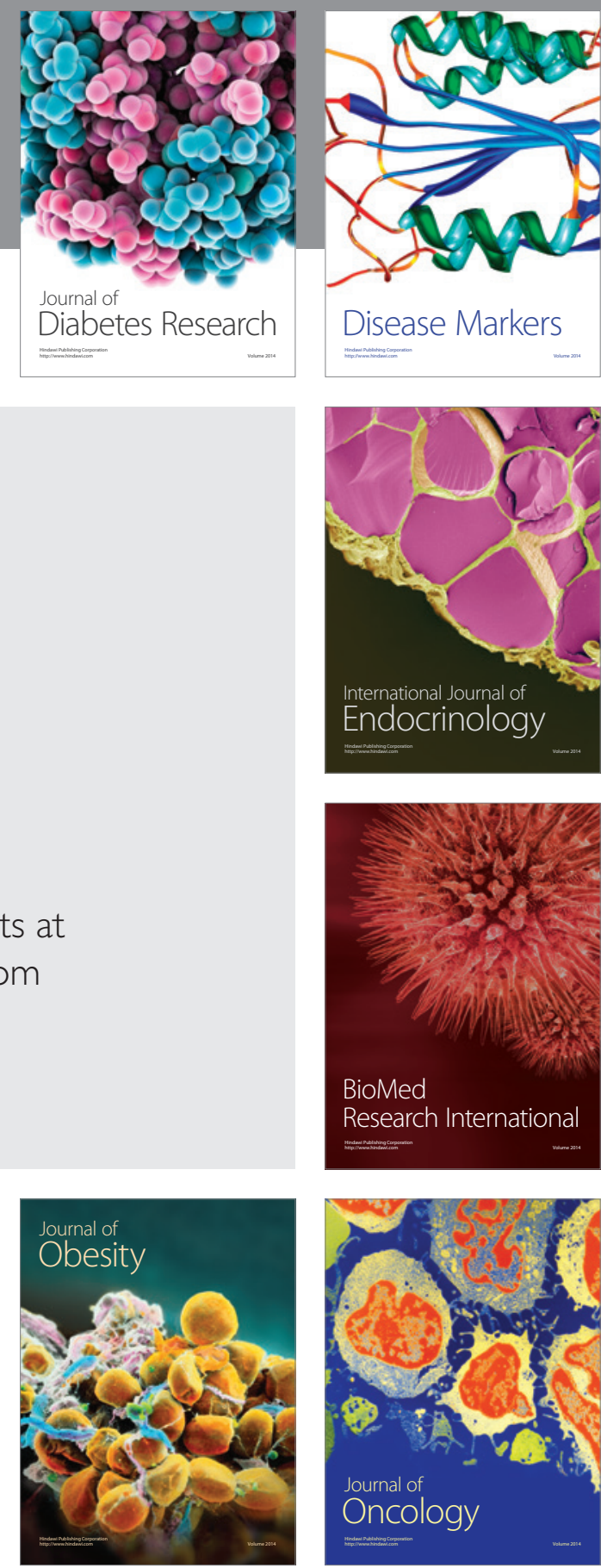

Disease Markers
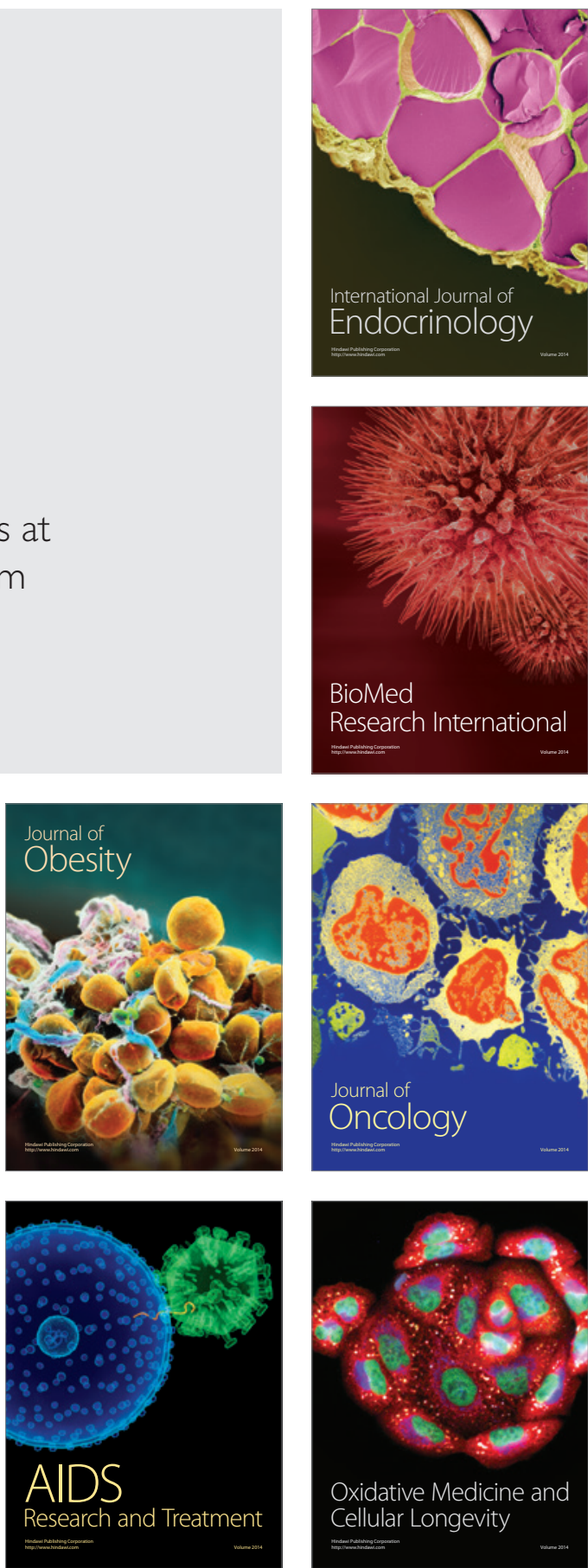